Sari Pediatri, Vol. 4, No. 2, September 2002: 63 - 66

\title{
Pengobatan Testosteron pada Mikropenis
}

\author{
Bambang Tridjaja, Jose RL Batubara, Aman Pulungan
}

\begin{abstract}
Mikropenis atau hipogenitalism adalah suatu keadaan penis dengan bentuk normal namun dengan ukuran kurang dari 2.5 SD di bawah rerata menurut umur dan status perkembangan pubertas. Pengukuran penis dilakukan secara fully stretched, menggunakan spatula kayu yang diletakkan sejajar dengan dorsum penis dan ditekan sampai simfisis pubis. Panjang penis adalah jarak dari simfisis pubis sampai ujung glans penis dan tidak dalam keadaan ereksi. Pengobatan mikropenis terhadap 23 anak dengan rerata usia 9.6 tahun dilakukan dengan pemberian testosteron ester intramuskular setiap 3 minggu sebanyak 4 kali. Pasca terapi penis bertambah panjang $85 \%$ dibandingkan sebelum terapi. Tidak terlihat adanya pertambahan usia tulang dengan protokol yang digunakan.
\end{abstract}

Kata kunci: mikropenis, testosteron ester

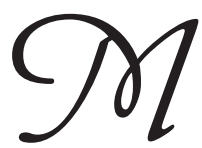

ikropenis atau hypogenitalism adalah suatu keadaan penis dengan bentuk normal namun dengan ukuran kurang dari 2,5 SD di bawah rerata menurut umur dan status perkembangan pubertas. ${ }^{1,2}$ Istilah mikropenis tidak digunakan bila terdapat kelainan morfologi penis lainnya seperti hipospadia, bentuk genital ambigus termasuk male pseudohermaphroditism. ${ }^{1}$ Mikropenis dapat disebabkan oleh hipogonadotropik hipogonadism, baik isolated maupun kombinasi dengan defisiensi pituitari lainnya, terutama defisiensi hormon pertumbuhan. Penyebab lainnya adalah hipogonadism primer atau bentuk incomplete androgen insensitivity syndrome. ${ }^{3-8}$ Sebagian besar mikropenis adalah idiopatik.

Panjang penis saat dewasa dapat diperkiraan dengan melihat panjang penis saat lahir. Penis yang sangat kecil sejak permulaan $(<3$ SD $)$, akan menimbulkan masalah seumur hidup. Bayi demikian perlu dinilai ulang status seksnya. ${ }^{4,9}$ Pengalaman klinis menunjukkan bahwa kunjungan untuk konsultasi mikropenis meningkat dari tahun ke tahun di Poliklinik Endokrinologi Anak RSCM. Terapi yang

\footnotetext{
Alamat Korespondensi:

Dr. Bambang Tridjaja, M.MPed., Sp.A(K).

Staf Subbagian Endokrinologi. Bagian Ilmu Kesehatan Anak FKUI-RSCM.

Jl. Salemba no. 6, Jakarta 10430.

Telepon: 021-3100669. Fax.: 021-390 7743.
}

dilakukan adalah pemberian testosteron ester $25 \mathrm{mg}$ intra muskular, sebanyak 4 dosis dengan interval 3 minggu. ${ }^{10}$ Biasanya terjadi pertambahan panjang penis yang bermakna bersama dengan peningkatan rugae skrotum disertai sedikit pertumbuhan rambut pubis. Terapi dehidrotestosteron transdermal diberikan bila tidak ada respons dengan terapi konvensional. ${ }^{5-7}$ Tujuan penelitian ini adalah untuk menilai hasil terapi testosteron pada anak yang berobat di poliklinik endokrinologi Bagian Ilmu Kesehatan Anak RSCM.

\section{Bahan dan Cara}

Penelitian dilakukan terhadap seluruh kasus yang datang di Poliklinik Endokrin Anak dengan mikropenis. Penelitian dilakukan dari Januari 1998 sampai dengan Desember 1999. Setelah memberikan informed consent dan tidak ada kelainan morfologis penis maka subyek diikutsertakan dalam penelitian.

\section{Pengukuran penis}

Pengukuran dilakukan secara fully stretched length measurement. Pemeriksa memegang glans penis antara ibu jari dan satu jari lainnya kemudian ditarik. Tangan yang satu mengukur panjang penis yang sudah ditarik, sementara spatula kayu diletakkan sejajar dengan penis sampai ke tulang pubis. Dari batas atas glans penis 
sampai dasar pubis dikatakan sebagai panjang penis. Preputium tidak diukur pada pengukuran panjang penis. Prosedur ini dilakukan untuk memastikan bagian penis yang terkubur dalam lemak subkutan ikut terukur sehingga tidak terjadi kesalahan diagnosis. ${ }^{1.2 .7}$ Pengukuran dilakukan tiga kali dan rerata dari ke tiga kali pengukuran digunakan sebagai data panjang penis.

Definisi mikropenis adalah apabila panjang penis kurang dari 2.5 SD untuk usia tanpa disertai kelainan anatomik penis. Pengukuran dilakukan oleh satu orang (peneliti) dengan variabilitas pengukuran $0.1 \mathrm{~cm}$. Setiap subyek yang memenuhi kriteria mikropenis mendapat injeksi testosteron ester $25 \mathrm{mg}$ intra muskular, sebanyak 4 dosis dengan interval 3 minggu. Evaluasi dilakukan pada awal, sebelum pemberian testosteron selanjutnya dan 6 bulan pasca pemberian testoteron terakhir. Sebelum pemberian testosteron dilakukan evaluasi hormonal dengan memeriksa kadar serum FSH, LH dan testosteron. Usia tulang diperiksa pada awal terapi dan 1 bulan setelah pengobatan terakhir. Kontrol terakhir untuk penelitian ini dilakukan setelah 6 bulan pengobatan berakhir. Selama pengobatan dilakukan pencatatan terhadap efek samping pengobatan.

Perhitungan statistik dilakukan dengan menghitung $Z$-score panjang penis. Tidak dilakukan uji kemaknaan pada penelitian ini karena target panjang penis normal tidak ditetapkan. Respons pengobatan dilakukan secara absolut dengan membandingkan panjang penis hasil terapi dengan standar. ${ }^{1}$ Apabila ukuran penis telah menjadi normal maka dikatakan respons baik.

\section{Hasil}

Pada penelitian ini didapatkan 23 penderita yang memenuhi kriteria mikropenis. Rerata usia penderita ketika datang pertama kali berobat 9.6 tahun. Seluruh penderita berada dalam status prepubertal. Pemeriksaan penunjang (hormon maupun usia tulang) yang dilakukan tidak mendapatkan kelainan. Pada Tabel 1 terlihat respons absolut (nominal) terhadap pemberian testosteron. Secara absolut terjadi penambahan panjang

Tabel 1. Hasil terapi testosteron pada mikropenis, Bagian Ilmu Kesehatan Anak FKUI-RSCM.

\begin{tabular}{cccccccc}
\hline No & $\begin{array}{c}\text { Umur } \\
(\mathrm{th})\end{array}$ & $\begin{array}{c}\text { Panjang awal } \\
(\mathrm{cm})\end{array}$ & $\begin{array}{c}\text { I } \\
(\mathrm{cm})\end{array}$ & $\begin{array}{c}\text { II } \\
(\mathrm{cm})\end{array}$ & $\begin{array}{c}\text { III } \\
(\mathrm{cm})\end{array}$ & $\begin{array}{c}\text { IV } \\
(\mathrm{cm})\end{array}$ & $\begin{array}{c}\text { Folllow up } \\
(\mathrm{cm})\end{array}$ \\
\hline 1 & 11 & 3 & 4,5 & 5,8 & 5,9 & - & - \\
2 & 11 & 3,8 & 4,6 & 6 & 6,3 & 4,8 & 5 \\
3 & 11 & 2 & 2,2 & 3 & 4,2 & 5,4 & 5,1 \\
4 & 14 & 4 & 5 & 5,5 & 5,6 & 6,3 & 7,2 \\
5 & 7 & 2,1 & 3,7 & 4,4 & 5 & 5,6 & - \\
6 & 12 & 3,1 & 5 & 6,4 & 6,5 & stop & - \\
7 & 9 & 3,2 & 4 & 5 & 5,6 & 5,6 & - \\
8 & 9 & 4 & 4,6 & 5,3 & 5,8 & - & - \\
9 & 11 & 2,1 & 3,5 & 4 & 4,1 & 5,2 & 5,5 \\
10 & 11 & 2,8 & 3,8 & 4,9 & 5 & 6 & - \\
11 & 8 & 3,2 & 3,3 & 4,3 & 5,5 & 5,5 & - \\
12 & 10 & 2,3 & 2,5 & 2,4 & 4,6 & 4,9 & 4,2 \\
13 & 13 & 3,6 & 5 & 5,1 & 5,5 & 5,8 & 5,8 \\
14 & 12 & 2,6 & 5 & 5,2 & 5,3 & 6,6 & - \\
15 & 3,2 & 3,6 & 3,7 & 4 & 4,5 & 5 & - \\
16 & 8 & 3,5 & 4,1 & 4,3 & 4,5 & - & - \\
17 & 11 & 3 & 3,4 & 4,2 & 4,9 & 4,9 & 4,4 \\
18 & 5 & 3,2 & 5 & 5,5 & 6 & 5,2 & - \\
19 & 11 & 3,3 & 3,6 & 3,9 & 4,1 & 4,7 & - \\
20 & 10 & 2,9 & 3,9 & 5 & 5,3 & 5,8 & - \\
21 & 8 & 3,7 & 5 & 6 & 7 & - & - \\
22 & 5 & 3,6 & 4,2 & 4,5 & 4,9 & 5,9 & - \\
23 & 11 & 2,3 & 2,8 & 2,9 & 4,8 & 5,7 & - \\
\hline
\end{tabular}

Keterangan:

I Suntikan pertama, II Suntikan kedua, III Suntikan ketiga, IV Suntikan keempat, Follow up: Panjang penis setelah 6 bulan selesai terapi 
penis sebesar $32 \%$ setelah penyuntikan pertama, dan kemudian penambahan ini menjadi 16.6\%. 15.8\% dan $7.6 \%$ setelah suntikan kedua, ketiga dan keempat. Pada akhir pengobatan rerata peningkatan absolut panjang penis $89 \%$ dibandingkan pada awal pengobatan dengan rentang yang cukup lebar antara 26 sampai 166\%. Empat anak tidak menyelesaikan terapi sampai tahap akhir dan follow up enam bulan pasca terapi hanya dilakukan pada 7 anak. Untuk perhitungan akhir yang menghentikan pengobatan tetap dievaluasi dengan menggunakan panjang penis pada saat mengundurkan diri sebagai panjang akhir penis.

Pada Tabel 2 terlihat bahwa pada akhir siklus terapi testosteron semua kasus sudah tidak menderita mikropenis lagi (SDS -0.64). Enam kasus (26\%) masih termasuk mikropenis setelah pemberian testosteron pertama. Tiga anak (13\%) belum berhasil menjadi normal pada pemberian testosteron kedua. Setelah pemberian testosteron ketiga, semua kasus sudah dapat dikatakan normal.

Selama pengobatan tidak ditemukan efek samping pengobatan yang berarti. Efek samping yang paling dikeluhkan adalah frekuensi ereksi yang cukup sering terutama pada hari pertama dan kedua pengobatan. Usia tulang selama pengobatan tidak mengalami peningkatan yang berarti bahkan selama pengobatan usia tulang tidak banyak berubah.

\section{Diskusi}

Berdasarkan data pasien mikropenis di Poliklinik Endokrin IKA RSCM, rerata usia pasien saat datang berobat pertama kali adalah 9,6 tahun. Hal ini sesuai dengan kurva pertumbuhan somatik dan genital,

Tabel 2. Hasil terapi mikropenis di Poliklinik Endokrin Bagian Ilmu Kesehatan Anak RSCM (Standard Deviation Score)

\begin{tabular}{cccccccc}
\hline No. & Umur (th) & SDS 0 & SDS I & SDS II & SDS III & SDS IV & $\begin{array}{c}\text { SDS follow up } \\
\text { 6 bulan }\end{array}$ \\
\hline 1 & 11 & $-3,3$ & $-1,8$ & $-0,5$ & $-0,4$ & $-0,4$ & - \\
2 & 11 & $-2,5$ & $-1,7$ & $-0,3$ & - & $-1,5$ & $-1,3$ \\
3 & 11 & $-4,3$ & $-4,1$ & $-3,3$ & $-2,1$ & $-0,9$ & $-1,2$ \\
4 & 14 & -3 & $-2,4$ & -2 & -2 & $-1,5$ & $+0,5$ \\
5 & 7 & $-4,1$ & $-2,4$ & $-1,7$ & $-1,0$ & $-0,4$ & - \\
6 & 12 & $-2,2$ & $-0,8$ & $+0,1$ & $+0,2$ & stop & - \\
7 & 9 & $-3,1$ & $-2,3$ & $-1,3$ & $-0,7$ & $-0,7$ & - \\
8 & 9 & $-2,3$ & $-1,7$ & -1 & $-0,5$ & $-0,5$ & - \\
9 & 11 & $-4,2$ & $-2,8$ & $-2,3$ & $-2,2$ & $-1,1$ & $-0,8$ \\
10 & 11 & $-3,5$ & $-2,5$ & $-1,4$ & $-1,3$ & $-0,3$ & - \\
11 & 8 & $-3,1$ & -3 & -2 & $-0,8$ & $-0,8$ & - \\
12 & 10 & -4 & $-3,8$ & $-3,9$ & $-1,7$ & $-1,4$ & $-2,1$ \\
13 & 13 & $-1,8$ & $-0,8$ & $-0,7$ & $-0,5$ & $-0,2$ & $-0,2$ \\
14 & 12 & $-2,5$ & $-0,8$ & $-0,7$ & $-0,6$ & $-0,2$ & - \\
15 & 3,2 & $-1,8$ & $-1,7$ & $-1,4$ & $-0,9$ & $-0,4$ & - \\
16 & 8 & $-2,8$ & $-2,2$ & -2 & $-1,8$ & - & - \\
17 & 11 & $-3,3$ & $-2,9$ & $-2,1$ & $-1,4$ & $-1,4$ & $-1,9$ \\
18 & $5-$ & $-2,9$ & $-1,0$ & $-0,5$ & - & $-0,8$ & - \\
19 & 11 & -3 & $-2,9$ & $-2,4$ & $-2,2$ & $-1,6$ & - \\
20 & 10 & $-3,4$ & $-2,4$ & $-1,3$ & -1 & $-0,5$ & - \\
21 & 8 & $-2,6$ & $-1,3$ & $-0,3$ & $+0,7$ & - & - \\
22 & 5 & -2 & $-1,4$ & $-1,1$ & $-0,7$ & $+0,3$ & - \\
23 & 11 & -4 & $-3,5$ & $-3,4$ & $-1,5$ & $-0,6$ & - \\
\hline
\end{tabular}

Keterangan:

SDS 0: skor SDS pada awal penelitian, SDS I: skor SDS setelah suntikan I, SDS II: skor SDS setelah suntikan II, SDS III: skor SDS setelah suntikan III, SDS IV: skor SDS setelah suntikan IV, SDS Follow up: SDS setelah 6 bulan terapi 
dimana menjelang pubertas grafik pertumbuhan genital paling jauh dari grafik pertumbuhan somatik sehingga ukuran penis yang kecil lebih jelas terlihat dan membawa pasien datang berobat. ${ }^{6}$

Aaronson ${ }^{10}$ merekomendasikan pemberian testosteron ester secara parenteral dengan dosis $25 \mathrm{mg}$ setiap 3 minggu sejumlah 4 kali. Kontrol dilakukan 2 minggu pasca suntikan terakhir. Pada neonatus dengan mikropenis, apabila hasilnya tidak memuaskan maka dapat diulang pada usia 4-5 tahun. Pada penelitian ini dengan protokol yang sesuai dengan anjuran Aaronson ternyata menghasilkan respons yang baik, tidak ada satu pasienpun yang gagal terapi. Pada pasien yang menghentikan pengobatan, semuanya telah menjadi normal kembali pada saat menyatakan henti. Pasien yang mengundurkan diri tetap diperhitungkan pada akhir penelitian. Pada saat datang pertama kali, rerata panjang penis adalah -3 SD. Setelah mendapat 4kali suntikan testosteron, rerata panjang penis menjadi $-0,64 \mathrm{SD}$ atau penambahan panjang penis sebanyak $78.8 \%$.

Pada akhir pengobatan rerata peningkatan absolut panjang penis $89 \%$ dibandingkan pada awal pengobatan dengan rentang yang cukup lebar antara 26 sampai $166 \%$. Terlihat pada penelitian ini adanya kecenderungan respons berbanding terbalik dengan ukuran penis pada awal terapi. Semakin jauh dari nilai rerata maka respons terhadap pengobatan lebih baik. Namun hal ini perlu penelitian lebih lanjut. Kami hanya mendapat data 7 pasien pada pemantauan 6 bulan setelah selesai terapi. Sesuai dengan kepustakaan, ${ }^{7}$ memang terdapat sedikit regresi yang sudah diantisipasi sebelumnya, yaitu sebesar $-0,3 \mathrm{SD}$, sehingga rerata panjang penis menjadi $-1 \mathrm{SD}$. Batubara mendapatkan bahwa pemberian testosteron $25 \mathrm{mg}$ setiap 3 minggu sejumlah 4 kali tidak mempercepat usia tulang anak yang datang dengan keluhan mikropenis baik idiopatik maupun non idiopatik. ${ }^{11}$ Pada penelitian ini usia tulang tidak mengalami percepatan. Selain itu efek samping pengobatan tidak ditemukan. Status pubertas pasien tidak terpacu akibat terapi dengan protokol yang digunakan pada penelitian ini.

Sebagai kesimpulan dapat dikatakan bahwa keluhan mikropenis terutama terjadi pada usia peripubertas pada saat terjadi disosiasi pertumbuhan fisik dan penis. Pemberian testosteron sangat bermanfaat pada mikropenis dengan respons terapi rerata dari panjang awal $-3 \mathrm{SD}$ menjadi $-0,64 \mathrm{SD}$ atau terjadi penambahan panjang penis sebesar 78\%.

Ucapan terima kasih kepada dr Esthernita DP yang telah membantu mengumpulkan data-data pasien.

\section{Daftar Pustaka}

1. Lee, O'Dea. Testes and variants of male sexual development. Dalam: Hung W, penyunting. Clinical pediatric endocrinology. St. Louis: Mosby, 1992. h. 280-90.

2. Kogan S J. Micropenis: etiologic and management considerations. Pediatric andrology 1991; 7. h. 197-207.

3. Walsh PC, Wilson JD, Allen TD, et al. Clinical and endocrinological evaluation of patients with congenital microphallus. J of Urol 1978. h. 120:90-5.

4. Woodhouse CRJ. Ambiguous genitalia and intersexuality-micropenis. Pediatric urology, 1997. h. 689-93.

5. Baskin LS, Sutherland RS, DiSandro M, Hayward SW, Lipschitz J, Cunha GR. The effect of testosteron on androgen receptors and human penile growth. http:// www.itsa.edu/uroweb/uro/faculty/baskin.html. Documents/micropenis.htm 24/11/98 (abstract).

6. Gilbert DA, Jordan GH, Devine CJ, Winslow BH, Schlossberg SM. Phallic construction in prepubertal and adolescent boys. J of Urol 1993; 149:1521-26.

7. Wales JKH. Pediatric endocrinology and growth. London: Mosby, 1985. h. 112-3.

8. Allen TD. Microphallus: clinical and endocrinological characteristics. J of Urol 1978; 119:750-3.

9. Choi SK, Han SW, Kim DH, Lignieres B. Transdermal dihydrotestosterone therapy and its effects on patients with microphallus. J of Urol 1993; 150:657-60.

10. Aaronson IA. Micropenis: medical and surgical implications. J of Urol 1994; 152:4-14.

11. Batubara JRL. Pengobatan testosteron pada mikropenis. Dibacakan di Symposium Ambiguus genitalia KONIKA IX Semarang 1993. 